\title{
Synthesis of novel multifunctional carbazole-based molecules and their thermal, electrochemical and optical properties
}

\author{
Nuray Altinolcek ${ }^{1}$, Ahmet Battal ${ }^{2,3}$, Mustafa Tavasli ${ }^{*}$, William J. Peveler ${ }^{3}$, Holly A. Yu ${ }^{3}$ \\ and Peter J. Skabara ${ }^{3}$
}

\author{
Full Research Paper \\ Address: \\ ${ }^{1}$ Department of Chemistry, Faculty of Science-Art, Uludag University, \\ 16059 Nilufer, Bursa, Turkey, ${ }^{2}$ Department of Elementary School \\ Education, Faculty of Education, Mus Alparslan University, 49100, \\ Mus, Turkey and ${ }^{3}$ WestCHEM, School of Chemistry, University of \\ Glasgow, Joseph Black Building, G128QQ Glasgow, UK \\ Email: \\ Mustafa Tavasli* - mtavasli@uludag.edu.tr \\ * Corresponding author \\ Keywords: \\ carbazole; electrochemistry; fluorescence; formyl group; \\ solvatochromism
}

\author{
Beilstein J. Org. Chem. 2020, 16, 1066-1074. \\ doi:10.3762/bjoc. 16.93 \\ Received: 10 March 2020 \\ Accepted: 06 May 2020 \\ Published: 19 May 2020 \\ Associate Editor: H. Ritter \\ () 2020 Altinolcek et al.; licensee Beilstein-Institut. \\ License and terms: see end of document.
}

\begin{abstract}
Two novel carbazole-based compounds $\mathbf{7 a}$ and $\mathbf{7 b}$ were synthesised as potential candidates for application in organic electronics. The materials were fully characterised by NMR spectroscopy, mass spectrometry, FTIR, thermogravimetric analysis, differential scanning calorimetry, cyclic voltammetry, and absorption and emission spectroscopy. Compounds $\mathbf{7 a}$ and $\mathbf{7 b}$, both of which were amorphous solids, were stable up to $291^{\circ} \mathrm{C}$ and $307^{\circ} \mathrm{C}$, respectively. Compounds $7 \mathbf{a}$ and $7 \mathbf{b}$ show three distinctive absorption bands: high and mid energy bands due to locally excited (LE) transitions and low energy bands due to intramolecular charge transfer (ICT) transitions. In dichloromethane solutions compounds 7a and $\mathbf{7 b}$ gave emission maxima at $561 \mathrm{~nm}$ and $482 \mathrm{~nm}$ with quantum efficiencies of $5.4 \%$ and $97.4 \% \pm 10 \%$, respectively. At positive potential, compounds $7 \mathbf{a}$ and $7 \mathbf{b}$ gave two different oxidation peaks, respectively: quasi-reversible at $0.55 \mathrm{~V}$ and $0.71 \mathrm{~V}$, and reversible at $0.84 \mathrm{~V}$ and $0.99 \mathrm{~V}$. At negative potentials, compounds $7 \mathbf{a}$ and $\mathbf{7 b}$ only exhibited an irreversible reduction peak at $-1.86 \mathrm{~V}$ and $-1.93 \mathrm{~V}$, respectively.
\end{abstract}

\section{Introduction}

Carbazole derivatives have found many different applications in a variety of technologically important areas, such as organic light emitting diodes (OLEDs), organic photovoltaics (OPVs), dye synthesised solar cells (DSSCs) and sensors [1,2]. In
OLEDs, carbazole derivatives are frequently used as host materials [3-5]. In this respect the most frequently used host materials are 1,3-bis $(N$-carbazolyl)benzene $(\mathrm{mCP})[6]$ and polyvinylcarbazole (PVK) [7]. Carbazole derivatives, either just by them- 
selves or in combination with iridium, are also used as emissive materials in OLEDs [8]. In this respect a molecule bearing a dithienylbenzothiadiazole unit and four alkyl-linked peripheral carbazole groups (named as TCTzC) is used in the construction of saturated red emissive OLEDs [9]. Carbazole-based homoleptic or heteroleptic iridium(III) complexes were also reported in the construction of different OLEDs [10-13]. In OPVs, carbazole derivatives are frequently used as small molecule p-type (electron-donating) materials or electron-accepting (n-type) materials with a variety of donor-acceptor combinations $[14,15]$. In sensor studies, carbazole derivatives are used as fluorophores. In this regard many different carbazole-based fluorophores are reported in the literature [16-19]. Some of the carbazole derivatives were used as colourimetric anion sensors [20], and others as biothiol sensors [21-23]. Research continues on carbazole derivatives to find new materials with novel properties. It is therefore essential that one should design a molecule that has multifunctional usage in many different areas of technology [24]. Since carbazole is a relatively inexpensive material with unique properties such as high hole-transporting mobility [12,25-27], pronounced thermal stability [2] and high fluorescent quantum yields $[28,29]$ our attention was focused on carbazole derivatives. In addition to that, carbazole is a rigid ar- omatic molecule [30] with many different modification sites for multifunctionalisation [31].

In this work, we designed two novel 2-( $N$-hexylcarbazol-3'-yl)4/5-formylpyridine compounds (7a and $7 \mathbf{b}$ ), where 4/5pyridinecarboxyaldehyde was attached to the 3-position of carbazole via the 2-position of the pyridine ring. These two compounds (7a and $\mathbf{7 b}$ ) can be used in OLEDs, solar cells and sensor studies either directly or with small modifications. Here we report the synthesis, full characterisation and properties of these two novel compounds ( $\mathbf{7 a}$ and $\mathbf{7 b}$ ).

\section{Results and Discussion Synthesis}

Compounds $\mathbf{7 a}$ and $\mathbf{7 b}$ were synthesised in four steps from carbazole (1) as depicted in Scheme 1. Carbazole (1) was first brominated with $\mathrm{N}$-bromosuccinimide in dimethylformamide [32,33]. This gave a mixture of mono- and dibromo products 2 and 3. Upon crystallisation 3-bromocarbazole (2) was obtained as white crystals in good yield. 3-Bromocarbazole (2) was then alkylated with 1-bromohexane in $50 \%$ aqueous $\mathrm{NaOH}$ in the presence of tetrabutylammonium iodide (TBAI) [33-35]. Upon chromatography 3-bromo-9-hexylcarbazole (4) was obtained as<smiles>[Y20]n1c2ccccc2c2cc(B(OC(C)C)OC(C)(C)C(C)(C)OB(OC(C)(C)C)c3ccc4c(c3)c3ccccc3n4[Y20])ccc21</smiles>

Scheme 1: Synthesis of compounds $7 \mathrm{a}$ and $7 \mathrm{~b}$ from carbazole 1. i) NBS, DMF, $0{ }^{\circ} \mathrm{C}$ to $\mathrm{rt}, 24 \mathrm{~h}$. ii) $n$-hexyl bromide, TBAI, NaOH $(50 \%), 77^{\circ} \mathrm{C}, 8 \mathrm{~h}$. iii) $\mathrm{B}_{2}$ (pin) $)_{2}, \mathrm{KOAc}, \mathrm{PdCl}_{2}\left(\mathrm{PPh}_{3}\right)_{2}, 1$, 4 -dioxane, $90^{\circ} \mathrm{C}, 24 \mathrm{~h}$. iv) $6 \mathrm{a} / 6 \mathbf{b}, \mathrm{K}_{2} \mathrm{CO}_{3}, \mathrm{PdCl}_{2}\left(\mathrm{PPh}_{3}\right)_{2}, 90^{\circ} \mathrm{C}, 6 \mathrm{~h}$. 
a liquid in good yield. 3-Bromo-9-hexylcarbazole (4) was then converted into the pinacol boronic ester by treating with bis(pinacolato)diboron in the presence of potassium acetate (KOAc) and dichlorobis(triphenylphosphine)palladium(II) in 1,4-dioxane [36,37]. Upon chromatography (9-hexylcarbazole3 -yl)boronic acid pinacol ester (5) was obtained as a liquid in good yield. (9-Hexylcarbazole-3-yl)boronic acid pinacol ester (5) was subjected to Suzuki-Miyaura reaction either with 2-bromopyridine-4-carbaldehyde (6a) or 2-bromopyridine-5carbaldehyde (6b) in the presence of potassium carbonate and bis(triphenylphosphine)palladium(II) dichloride in tetrahydrofuran [2]. Upon repeated purification by chromatography, compounds $7 \mathbf{a}$ and $\mathbf{7 b}$ were obtained as liquids in good yields (Scheme 1). Compounds $\mathbf{7 a}$ and $\mathbf{7 b}$ were fully characterised by NMR, FTIR, MS, elemental analysis, TGA, DSC, CV, and absorption and emission spectroscopy. The data are given in Supporting Information File 1.

\section{Thermal properties}

The thermal properties of compounds $\mathbf{7 a}$ and $\mathbf{7 b}$ were investigated by thermogravimetric analyses (TGA) and differential scanning calorimetry (DSC). For TGA, compounds $\mathbf{7 a}$ and $\mathbf{7 b}$ were heated at $20{ }^{\circ} \mathrm{C} / \mathrm{min}$ under nitrogen atmosphere. The decomposition temperatures $\left(T_{\mathrm{d}}{ }^{5 \%}\right)$ corresponding to $5 \%$ weight losses for $\mathbf{7 a}$ and $\mathbf{7 b}$ were $291{ }^{\circ} \mathrm{C}$ and $307^{\circ} \mathrm{C}$, respectively. For DSC, compounds $7 \mathbf{a}$ and $7 \mathbf{b}$ were first heated to $450{ }^{\circ} \mathrm{C}$ and then cooled down to room temperature at $20^{\circ} \mathrm{C} / \mathrm{min}$ under a nitrogen atmosphere. Compounds $\mathbf{7 a}$ and $\mathbf{7 b}$ showed only clear melting transitions $\left(T_{\mathrm{m}}\right)$ at $95{ }^{\circ} \mathrm{C}$ and $86^{\circ} \mathrm{C}$, respectively. Upon first cooling and second heating, no phase transitions were observed at all. TGA and DSC curves of compounds $\mathbf{7 a}$ and $\mathbf{7 b}$ are depicted in Figure 1. Thermal properties of compounds 7a and $\mathbf{7 b}$ are also summarised in Table 1.
Table 1: Thermal properties of compounds $7 \mathbf{a}$ and $\mathbf{7 b}$.

\begin{tabular}{lll} 
compound & $T_{\mathrm{m}}\left({ }^{\circ} \mathrm{C}\right)$ & $T_{\mathrm{d}}{ }^{5 \%}\left({ }^{\circ} \mathrm{C}\right)$ \\
\hline $7 \mathbf{a}$ & 95 & 291 \\
$7 \mathbf{b}$ & 86 & 307
\end{tabular}

\section{Electrochemical properties}

The redox behaviour of compounds $7 \mathbf{a}$ and $7 \mathbf{b}$ was investigated by cyclic voltammetry in dichloromethane solution under argon atmosphere using tetrabutylammonium hexafluorophosphate as the electrolyte (Figure 2). A platinum disk was used as a working electrode, silver wire as the reference electrode and platinum wire as the counter electrode. The ferrocene-ferrocenium redox couple was used as an internal reference.

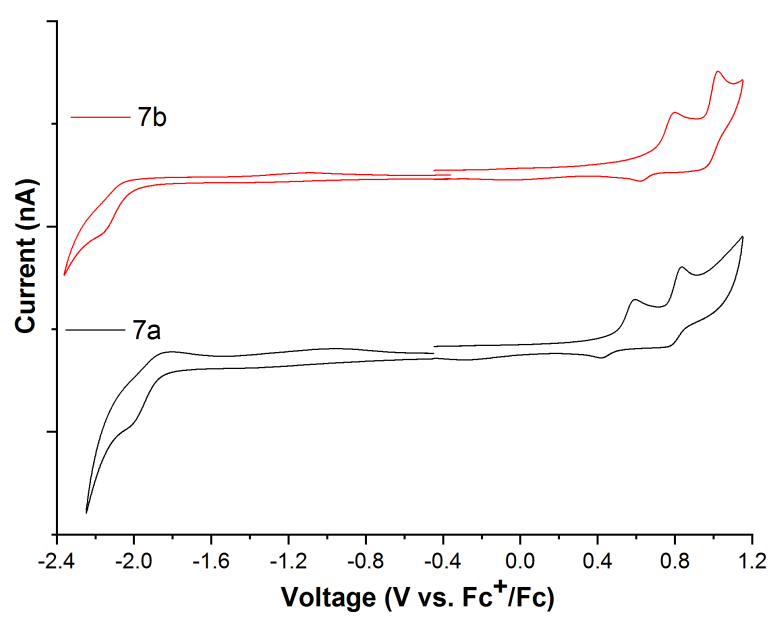

Figure 2: Cyclic voltammograms of compounds $7 \mathbf{a}$ and $\mathbf{7 b}$ in dichloromethane under argon atmosphere at room temperature.
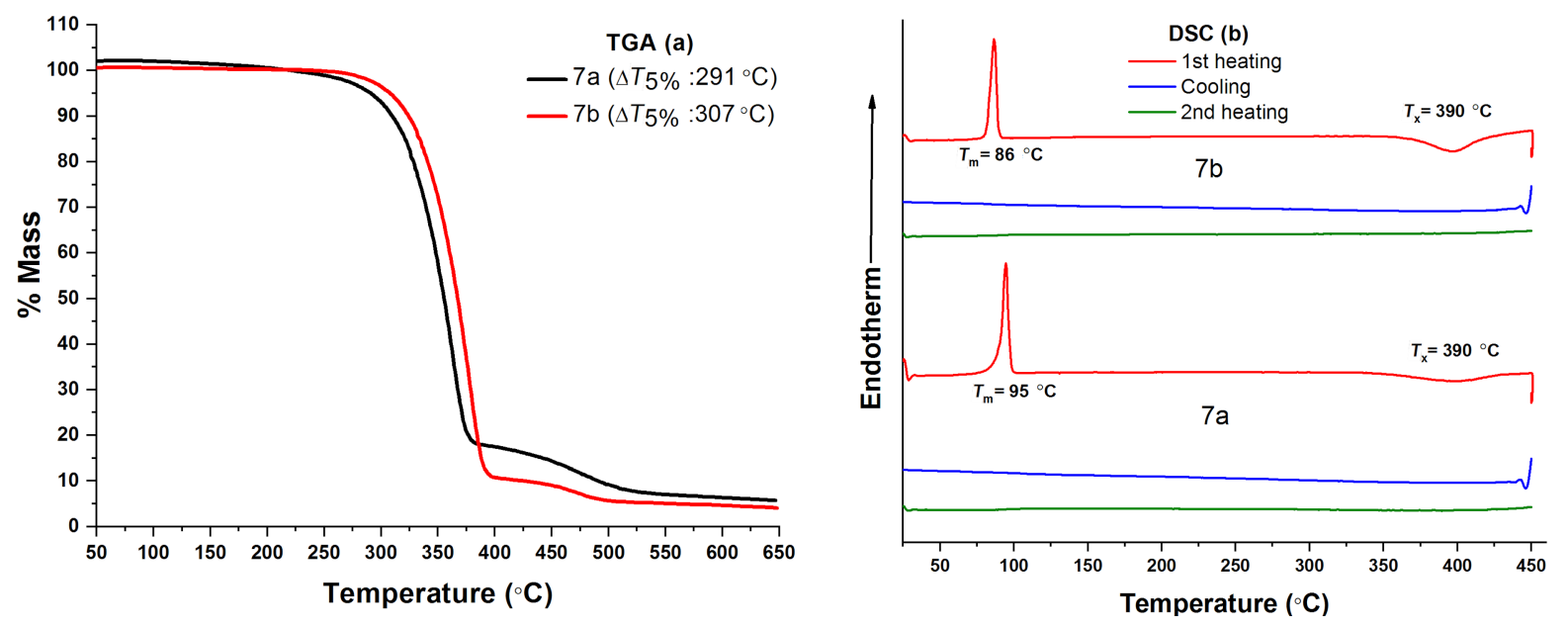

Figure 1: TGA (a) and DSC (b) curve of the compounds 7a and 7b. 
At positive potentials, compounds $\mathbf{7 a}$ and $\mathbf{7 b}$ exhibited two oxidation peaks; one is quasi-reversible at $0.55 \mathrm{~V}$ (7a) and $0.71 \mathrm{~V}$ (7b), and the other is reversible at $0.84 \mathrm{~V}$ (7a) and $0.99 \mathrm{~V}(7 \mathbf{b})$ At negative potentials, compounds $\mathbf{7 a}$ and $\mathbf{7 b}$ only exhibited an irreversible reduction peak at $-1.86 \mathrm{~V}$ and $-1.93 \mathrm{~V}$, respectively. The highest occupied molecular orbital and the lowest unoccupied molecular orbital energy levels ( $\left.E_{\mathrm{HOMO}}, E_{\mathrm{LUMO}}\right)$ of compounds $\mathbf{7 a}$ and $\mathbf{7 b}$ were also calculated from the half-way anodic oxidation and onset cathodic reduction peak potentials, with respect to the energy level of ferrocene $(4.8 \mathrm{eV}$ below vacuum level) [38] by using the following equations; [39] $E_{\mathrm{HOMO}}=-\left(4.8+E_{1 / 2}{ }^{\mathrm{ox}}\right)$ and $E_{\mathrm{LUMO}}=-\left(4.8+E_{\text {onset }}{ }^{\text {red }}\right)$. The HOMO-LUMO energy gap was calculated both from electrochemical data using Equation 1 and from optical data using Equation 2 [25,40,41].

$$
\begin{gathered}
E_{\mathrm{g}}{ }^{\mathrm{elec}}=E_{\mathrm{LUMO}}-E_{\mathrm{HOMO}} \\
E_{\mathrm{g}}{ }^{\mathrm{abs}}=1240 / \lambda_{\text {onset }}^{\mathrm{abs}}
\end{gathered}
$$

The optical energy gap $\left(E_{\mathrm{g}}{ }^{\mathrm{o}}\right)$ was higher than the electrochemical energy gap $\left(E_{\mathrm{g}}{ }^{\mathrm{e}}\right)$ for compounds $\mathbf{7 a}$ and $\mathbf{7 b}$. The oxidation and reduction potentials and the HOMO-LUMO energy levels of both compounds are summarised in Table 2 and the energy levels are depicted in Figure 3.

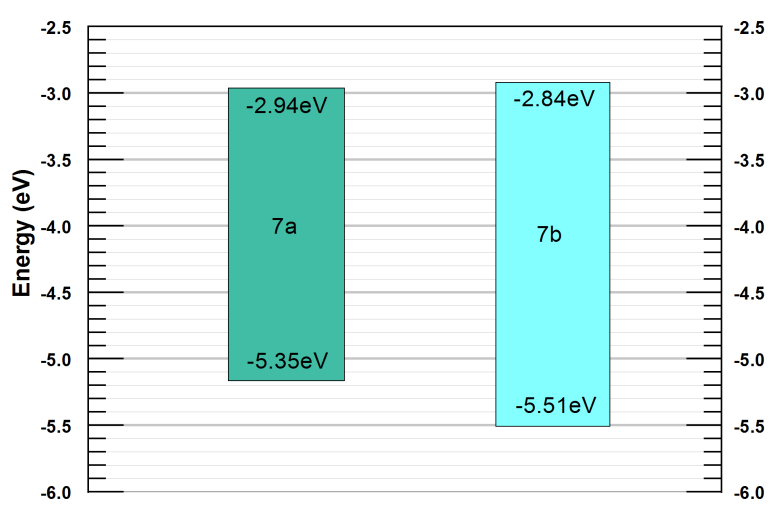

Figure 3: Energy levels of compounds $7 \mathbf{a}$ and $7 \mathbf{b}$

\section{Optical properties}

The absorption properties of compounds $7 \mathbf{a}$ and $\mathbf{7 b}$ were investigated in dichloromethane using a Duetta Fluorescence and Absorbance Spectrometer. Each compound (7a/7b) displayed three distinctive absorption bands in the UV-vis spectra: high energy bands and mid energy bands were assigned to $\pi-\pi^{*}$ and $n-\pi^{*}$ transitions, whereas the low energy bands were assigned to an intramolecular charge transfer (ICT) transition. The ICT band of $\mathbf{7 b}$ at $373 \mathrm{~nm}$ was more intense than the ICT band of 7a at $378 \mathrm{~nm}$. This observation confirms that conjugation enhances ICT band intensity [42]. In $\mathbf{7 b}$, the formyl group is at the para position to the carbazole ring, thus giving rise to conjugation. In 7a, however, the formyl group is at the meta position to the carbazole ring.

The photoluminescence (PL) properties of compounds 7a and 7b were investigated in dichloromethane using a Duetta Fluorescence and Absorbance Spectrometer. Compounds 7a and $7 \mathbf{b}$ gave emission maxima at $561 \mathrm{~nm}$ and $482 \mathrm{~nm}$, respectively. The UV-vis and PL spectra of the compounds are given in Figure 4.

\section{Solvatochromism}

In general, ICT-based absorption and emission bands show solvent dependency. This is better known as solvatochromism. The ICT behaviour of compounds $7 \mathbf{a}$ and $7 \mathbf{b}$ was further investigated in different solvents. Normalised UV-vis spectra of compounds $7 \mathbf{a}$ and $\mathbf{7 b}$ in different solvents are depicted in Figure 5. The spectral profiles remained almost unchanged in different solvents, but there is greater variance in the spectra of compound $\mathbf{7 b}$.

The PL spectra of compounds $\mathbf{7 a}$ and $\mathbf{7 b}$ displayed either dual emission bands or a single emission band. This was dependent on the excitation wavelength chosen and the solvent used. It is believed that the dual emission was due to mixed locally excited (LE) and intramolecular charge transfer (ICT) states and the single emission was due to the ICT state. Photoluminescence (PL) spectra of compounds $\mathbf{7 a}$ and $\mathbf{7 b}$ in different solvents are shown in Figure 6.

Upon excitation at $\pi-\pi^{*} / \mathrm{n}-\pi^{*}$ bands $\left(\lambda_{\mathrm{exc}}=245-349 \mathrm{~nm}\right.$ for $7 \mathbf{a}$ and 248-356 nm for 7b), the PL spectra of compound 7a in most solvents depicted dual emission bands, one from the

Table 2: Oxidation, reduction and energy gap of compounds $7 \mathbf{a}$ and $\mathbf{7 b}$.

\begin{tabular}{ccccc} 
compound & $E_{1 / 2}{ }^{\mathrm{ox}}(\mathrm{V})$ & $E_{\text {onset }}^{\mathrm{red}}(\mathrm{V})$ & $E_{\mathrm{LUMO}}(\mathrm{eV})$ & $E_{\mathrm{HOMO}}(\mathrm{eV})$ \\
\hline 7a & $0.55,0.84$ & -1.86 & -2.94 & -5.35 \\
$7 \mathbf{b}$ & $0.71,0.99$ & -1.96 & -2.84 & -5.51
\end{tabular}



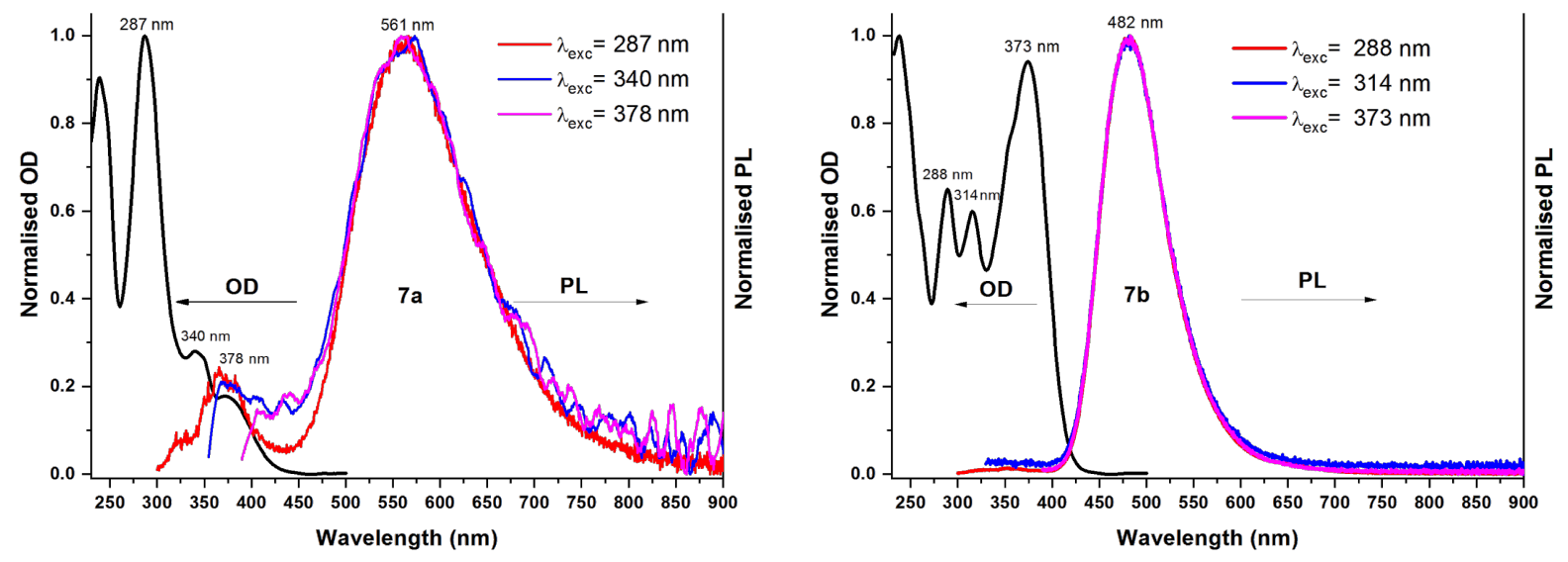

Figure 4: Normalised UV-vis and PL spectra of compounds $7 \mathbf{a}$ and $7 \mathbf{b}$ in dichloromethane.
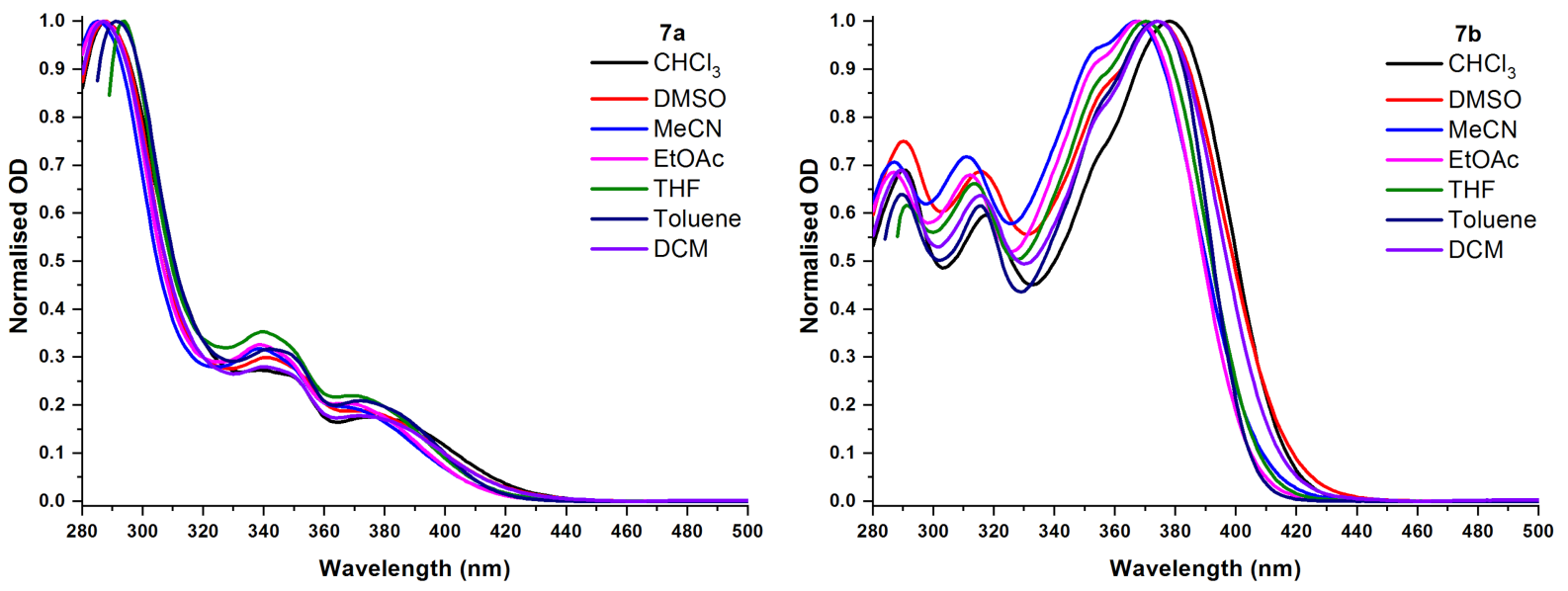

Figure 5: Normalised UV-vis spectra of compounds 7a and 7b in different solvents.
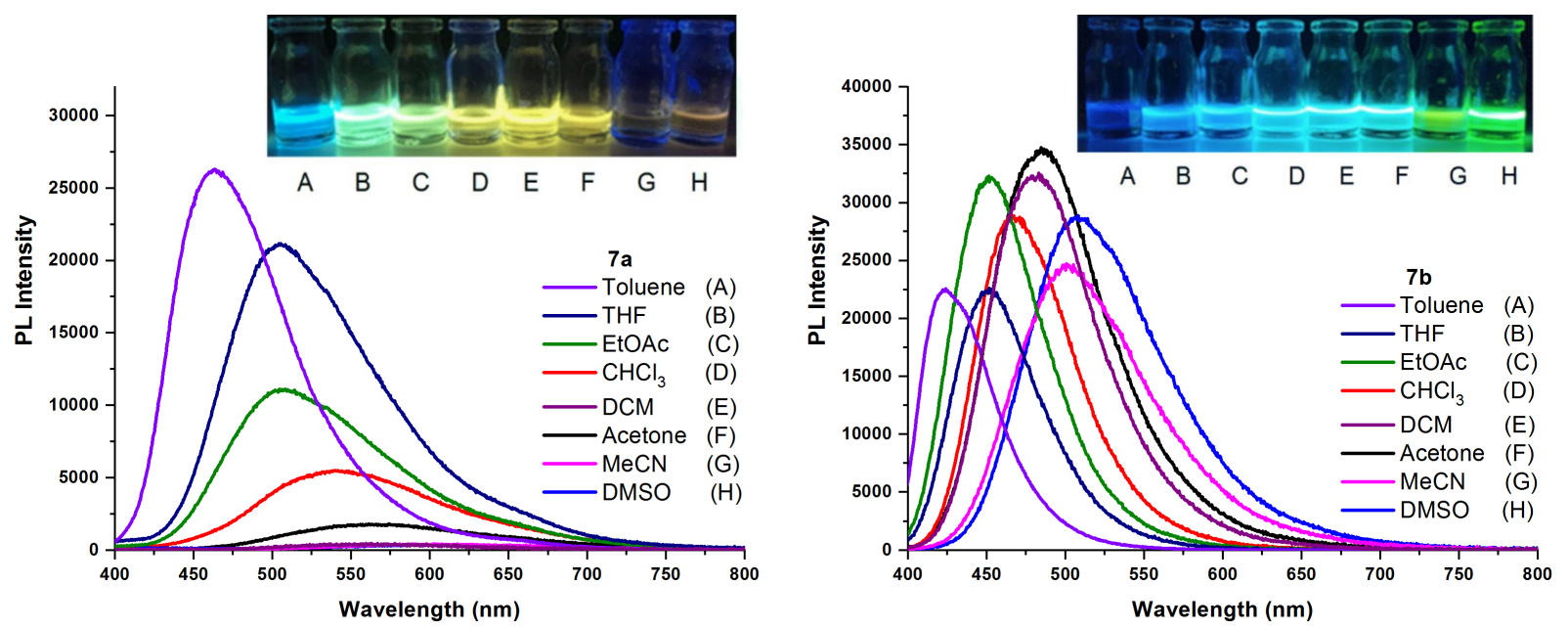

Figure 6: PL spectra of compounds $7 \mathbf{a}$ and $7 \mathbf{b}$ in different solvents $(A-H)$. 
locally excited state and one from ICT. On the other hand, the PL spectra of compound $\mathbf{7 b}$ in most solvents interestingly depicted only a single emission band from ICT. Upon excitation at the ICT band $\left(\lambda_{\mathrm{exc}}=370-377 \mathrm{~nm}\right.$ for $7 \mathbf{a}$ and $367-378 \mathrm{~nm}$ for $\mathbf{7 b}$ ), only a single emission band was observed for both compounds (7a and 7b). As seen in Figure 6, a redshift was observed in the emission maxima as the microscopic solvent polarity [43,44], $E_{\mathrm{T}}(30)$, increased from toluene to dimethyl sulfoxide (see also Table 3). A $141 \mathrm{~nm}$ red-shift was observed for 7a (from $465 \mathrm{~nm}$ to $606 \mathrm{~nm}$ ) and an $86 \mathrm{~nm}$ redshift was observed for $\mathbf{7 b}$ (from $423 \mathrm{~nm}$ to $509 \mathrm{~nm}$ ). In comparison for $\mathbf{7 b}$, this red-shift was more pronounced for $\mathbf{7 a}$. This indicates that the excited state dipole moment is much greater than the ground state dipole moment.

\section{Quantum yields}

The relative fluorescent quantum yields $\left(\phi_{\mathrm{FL}}\right)$ of compounds $\mathbf{7 a}$ and $\mathbf{7 b}$ were determined in dichloromethane by using rhodamine $\mathrm{B}\left(\phi_{\mathrm{FL}}=49 \%\right.$ at $\left.\lambda_{\mathrm{exc}}=355 \mathrm{~nm}\right)$ in ethanol as reference [45]. $\phi_{\mathrm{FL}}$ of compounds $7 \mathbf{a}$ and $\mathbf{7 b}$ was $5.4 \%$ and $97.4 \%$, respectively. An estimated error in quantum yield calculations is ca. $10 \%$. The details of the calculations are given in Supporting Information File 1. Surprisingly, compound $\mathbf{7 b}$, in which the formyl group is at the para position to the carbazole ring, was much more emissive than compound $\mathbf{7 a}$, in which the formyl group is at the meta position to the carbazole ring.

\section{Conclusion}

In this work, two novel compounds $\mathbf{7 a}$ and $\mathbf{7 b}$ were successfully synthesised in good yields and demonstrated good thermal stability. Compounds $\mathbf{7 a}$ and $\mathbf{7 b}$ showed intramolecular charge transport properties with positive solvatochromism. Whilst 7a showed very low emission intensity, $\mathbf{7 b}$ showed very high emission intensity. It is noted that the conjugation in compound $\mathbf{7 b}$ encompasses the $\mathrm{N}$ atom of the carbazole ring and the formyl functionality (viz. the donor/acceptor units of the ICT component), whereas the link by conjugation between the same functionalities in $\mathbf{7 a}$ is missing. The resulting stronger ICT compo- nent in $\mathbf{7 b}$ explains the big difference in photophysical properties.

\section{Experimental}

All reagents were standard reagent grade and purchased from Sigma-Aldrich, Merck and Alfa Aesar. Inert reactions were performed under an argon atmosphere. Nuclear magnetic resonance (NMR) spectra were obtained on an Agilent Premium Compact NMR spectrometer (600 MHz for ${ }^{1} \mathrm{H}$ NMR, $150 \mathrm{MHz}$ for ${ }^{13} \mathrm{C}$ NMR) with tetramethylsilane as internal standard. Elemental analysis was performed on a Costech Elemental system. The IR spectra were obtained (4000-400 $\left.\mathrm{cm}^{-1}\right)$ using a Shimadzu IRAffinity-1S Fourier transform infrared spectrophotometer. The mass spectra were obtained by Bruker microTOFq mass spectrometers to obtain low- and high-resolution spectra using electron ionisation (EI) or electrospray ionisation (ESI) techniques. UV, PL and photoluminescence quantum yields were measured on a Duetta two-in-one fluorescence and absorbance spectrometer from Horiba Scientific. Both absorption and emission solutions for reference and samples had a concentration of $10^{-6} \mathrm{M}$. CV measurements were obtained using a $\mathrm{CH}$ Instruments $602 \mathrm{E}$ electrochemical workstation with iR compensation using dry dichloromethane. Thermogravimetric analysis was conducted using a Netzsch TG 209 F3 Tarsus Thermogravimetric Analyser under a constant flow of nitrogen. Differential scanning calorimetry was determined on a Netzsch DSC 214 Polyma instrument.

3-Bromocarbazole (2): 2 was synthesised as reported previously [32,33]. A solution of $N$-bromosuccinimide (1.1 g, $5.98 \mathrm{mmol}$ ) in dimethylformamide was added dropwise to a solution of carbazole $(\mathbf{1}, 1 \mathrm{~g}, 5.96 \mathrm{mmol})$ in dimethylformamide $(15 \mathrm{~mL})$ at $0{ }^{\circ} \mathrm{C}$. The reaction mixture was then stirred at room temperature for $24 \mathrm{~h}$. The reaction was poured into distilled water to give a cream coloured precipitate. The precipitate was filtered off under vacuum and washed with distilled water $(3 \times 20 \mathrm{~mL})$. The precipitate was dissolved in ethyl acetate, dried with sodium sulfate and filtered. Upon concentra-

\begin{tabular}{|c|c|c|c|}
\hline entry & solvents, $\mathrm{E}_{\mathrm{T}}(30)$ & $7 \mathbf{a}\left(\lambda_{\mathrm{em}}, \mathrm{nm}\right)$ & 7b $\left(\lambda_{\mathrm{em}}, \mathrm{nm}\right)$ \\
\hline$A$ & toluene, 33.0 & 465 & 423 \\
\hline$B$ & tetrahydrofuran, 37.4 & 505 & 452 \\
\hline C & ethyl acetate, 38.1 & 509 & 452 \\
\hline $\mathrm{D}$ & chloroform, 39.1 & 543 & 467 \\
\hline$E$ & dichloromethane, 40.7 & 561 & 482 \\
\hline $\mathrm{F}$ & acetone, 42.2 & 564 & 486 \\
\hline $\mathrm{G}$ & acetonitrile, 45.6 & 600 & 501 \\
\hline $\mathrm{H}$ & dimethyl sulfoxide, 45.1 & 606 & 509 \\
\hline
\end{tabular}


tion under reduced pressure the crude product was obtained as a brown solid. After crystallisation of the crude product with chloroform, the pure product 2 (692 mg, 47\%) was obtained as white crystals. $R_{\mathrm{f}}$ (ethyl acetate/hexane, $1: 6 \mathrm{v} / \mathrm{v}$ ): 0.43; melting point: $200-201{ }^{\circ} \mathrm{C} ;{ }^{1} \mathrm{H} \mathrm{NMR}\left(600 \mathrm{MHz}, \mathrm{CDCI}_{3}\right) \delta$ (ppm) 8.19 $(\mathrm{d}, J=1.9 \mathrm{~Hz}, 1 \mathrm{H}), 8.08(\mathrm{~s}, 1 \mathrm{H}), 8.02(\mathrm{dd}, J=7.7,1.1 \mathrm{~Hz}, 1 \mathrm{H})$, $7.50(\mathrm{dd}, J=8.5,1.9 \mathrm{~Hz}, 1 \mathrm{H}), 7.47-7.40(\mathrm{~m}, 2 \mathrm{H}), 7.31(\mathrm{~d}, J=$ $8.6 \mathrm{~Hz}, 1 \mathrm{H}), 7.25(\mathrm{td}, J=6.3,1.8 \mathrm{~Hz}, 1 \mathrm{H})$.

3-Bromo-9-hexylcarbazole (4): 4 was synthesised as reported previously [33-35]. A mixture of 3-bromocarbazole (2, $1.5 \mathrm{~g}$, $6.0 \mathrm{mmol}), 1$-bromohexane $(4.0 \mathrm{~g}, 24.3 \mathrm{mmol})$, tetrabutylammonium iodide (225 mg, $0.6 \mathrm{mmol})$ and aqueous sodium hydroxide ( $26 \mathrm{~mL}, 50 \%$ ) was heated at $77^{\circ} \mathrm{C}$ for $8 \mathrm{~h}$. The product was extracted with dichloromethane $(3 \times 20 \mathrm{~mL})$, and the combined extracts were dried over sodium sulfate and then filtered. Upon concentration under reduced pressure, the crude product was obtained as a light yellow liquid. The crude product was purified by flash column chromatography (2:98 triethylamine/hexane v/v). Pure compound 4 (1.7 g, 84\%) was obtained as a colourless liquid which solidified on standing. $R_{\mathrm{f}}$ (hexane): 0.3 , melting point: $48-49{ }^{\circ} \mathrm{C} ;{ }^{1} \mathrm{H} \mathrm{NMR}(600 \mathrm{MHz}$, $\left.\mathrm{CDCI}_{3}\right) \delta(\mathrm{ppm}) 8.20(\mathrm{~d}, J=1.9 \mathrm{~Hz}, 1 \mathrm{H}), 8.04(\mathrm{~d}, J=7.8$, $1.1 \mathrm{~Hz}, 1 \mathrm{H}), 7.53(\mathrm{dd}, J=8.6,1.9 \mathrm{~Hz}, 1 \mathrm{H}), 7.48(\mathrm{td}, J=8.3$, $1.2 \mathrm{~Hz}, 1 \mathrm{H}), 7.40(\mathrm{~d}, J=8.2 \mathrm{~Hz}, 1 \mathrm{H}), 7.28(\mathrm{~d}, J=8.6 \mathrm{~Hz}, 1 \mathrm{H})$, $7.24(\mathrm{t}, 1 \mathrm{H}), 4.27(\mathrm{t}, J=7.3 \mathrm{~Hz}, 3 \mathrm{H}), 1.85(\mathrm{p}, J=7.4 \mathrm{~Hz}, 3 \mathrm{H})$, $1.34-1.23(\mathrm{~m}, 6 \mathrm{H}), 0.86(\mathrm{t}, J=7.0 \mathrm{~Hz}, 4 \mathrm{H})$.

(9-Hexylcarbazole-3-yl)boronic acid pinacol ester (5): 5 was synthesised as reported previously [36,37]. Bis(pinacolato)diboron (423 mg, $1.7 \mathrm{mmol}$ ), potassium acetate (446 mg, $4.5 \mathrm{mmol}$ ) and dichlorobis(triphenylphosphine)palladium(II) ( $35 \mathrm{mg}, 0.05 \mathrm{mmol}$ ) catalyst were added to a 3-bromo- $N$-hexylcarbazole $(4,500 \mathrm{mg}, 1.5 \mathrm{mmol})$ solution in 1,4-dioxane $(15 \mathrm{~mL})$. The reaction mixture was heated at $90{ }^{\circ} \mathrm{C}$ for $24 \mathrm{~h}$ under an argon atmosphere. The crude product was extracted with dichloromethane $(3 \times 20 \mathrm{~mL})$, and the combined extracts were dried over sodium sulfate and then filtered. Upon concentration under reduced pressure, the crude product was obtained as a brown-black liquid. The product was purified by flash column chromatography $\left(\mathrm{CH}_{2} \mathrm{Cl}_{2} /\right.$ hexane $\left.1: 4 \mathrm{v} / \mathrm{v}\right)$. Pure product 5 (404 mg, 71\%) was obtained as a colourless liquid. $R_{\mathrm{f}}$ $\left(\mathrm{CH}_{2} \mathrm{Cl}_{2}\right.$ /hexane, $\left.1: 2 \mathrm{v} / \mathrm{v}\right): 0.32,{ }^{1} \mathrm{H} \mathrm{NMR}\left(600 \mathrm{MHz}, \mathrm{CDCI}_{3}\right) \delta$ (ppm) $8.60(\mathrm{~s}, 1 \mathrm{H}), 8.13(\mathrm{~d}, J=7.6 \mathrm{~Hz}, 1 \mathrm{H}), 7.91(\mathrm{dd}, J=8.1$, $2.5 \mathrm{~Hz}, 1 \mathrm{H}), 7.46(\mathrm{t}, J=7.4 \mathrm{~Hz}, 1 \mathrm{H}), 7.42-7.36(\mathrm{~m}, 2 \mathrm{H}), 7.23$ $(\mathrm{d}, J=7.6 \mathrm{~Hz}, 1 \mathrm{H}), 4.30(\mathrm{t}, J=7.0 \mathrm{~Hz}, 2 \mathrm{H}), 1.86(\mathrm{t}, J=7.6 \mathrm{~Hz}$, 2H), $1.49-1.15(\mathrm{~m}, 18 \mathrm{H}), 0.85(\mathrm{t}, J=7.1 \mathrm{~Hz}, 3 \mathrm{H})$.

Compound 7a: (9-Hexylcarbazol-3-yl)boronic acid pinacol ester (5, $447 \mathrm{mg}, 1.2 \mathrm{mmol})$, 2-bromopyridine-4-carbaldehyde (6a, $147 \mathrm{mg}, 0.8 \mathrm{mmol})$, potassium carbonate $(1 \mathrm{M}, 9.6 \mathrm{~mL})$ and dichlorobis(triphenylphosphine)palladium(II) (40 mg, $0.06 \mathrm{mmol})$ were dissolved in tetrahydrofuran $(20 \mathrm{~mL})$. The reaction mixture was refluxed for $24 \mathrm{~h}$ under an argon atmosphere. After removing the solvent, the crude product was dissolved in dichloromethane and washed with water $(3 \times 20 \mathrm{~mL})$. The combined extracts were dried over sodium sulfate and then filtered. Upon concentration under reduced pressure, the crude product was obtained as a dark green-yellow liquid. The crude product was first purified by flash column chromatography (1:3 $\mathrm{CH}_{2} \mathrm{Cl}_{2} /$ hexane $\mathrm{v} / \mathrm{v}$ ) followed by preparative thin-layer chromatography $\left(4: 2: 1\right.$ hexane/ $\left.\mathrm{CHCI}_{3} / \mathrm{MeOH} \mathrm{v} / \mathrm{v} / \mathrm{v}\right)$. The pure product $7 \mathbf{a}(176 \mathrm{mg}, 63 \%)$ was obtained as a yellow liquid which solidified on standing. $R_{\mathrm{f}}$ (dichloromethane/hexane, $1: 1 \mathrm{v} / \mathrm{v}$ ): 0.3 , melting point: $91-93{ }^{\circ} \mathrm{C},{ }^{1} \mathrm{H} \mathrm{NMR}\left(600 \mathrm{MHz}, \mathrm{CDCI}_{3}\right) \delta(\mathrm{ppm})$ $10.17(\mathrm{~s}, 1 \mathrm{H}), 8.95(\mathrm{dd}, J=4.8,0.9 \mathrm{~Hz}, 1 \mathrm{H}), 8.83(\mathrm{~d}, J=$ $1.8 \mathrm{~Hz}, 1 \mathrm{H}), 8.24(\mathrm{~s}, 1 \mathrm{H}), 8.23-8.16(\mathrm{~m}, 3 \mathrm{H}), 7.58(\mathrm{dd}, J=4.9$, $1.4 \mathrm{~Hz}, 1 \mathrm{H}), 7.53-7.46(\mathrm{~m}, 3 \mathrm{H}), 7.44(\mathrm{~d}, J=8.0 \mathrm{~Hz}, 1 \mathrm{H}), 7.28$ $(\mathrm{dt}, J=7.3,0.8 \mathrm{~Hz}, 1 \mathrm{H}), 4.33(\mathrm{t}, J=7.3 \mathrm{~Hz}, 3 \mathrm{H}), 1.90(\mathrm{p}, J=$ $7.7 \mathrm{~Hz}, 3 \mathrm{H}), 1.47-1.37$ (m, 3H), 1.37-1.19 (m, 6H), 0.87 (t, $J=$ $7.1 \mathrm{~Hz}, 4 \mathrm{H}) ;{ }^{13} \mathrm{C}$ NMR $\left(600 \mathrm{MHz}, \mathrm{CDCI}_{3}\right) \delta(\mathrm{ppm}) 192.0$, $160.0,150.9,142.5,141.5,141.0,129.1,126.1,124.8,123.4$, $123.1,120.6,119.4,119.3,119.3,118.6,109.0,108.9,43.3$, 31.6, 29.0, 27.0, 22.5, 14.0; FTIR $\left(\mathrm{cm}^{-1}\right): 2956,2924,2911$, 2872, 2851, 1697; anal. calcd for $\mathrm{C}_{24} \mathrm{H}_{24} \mathrm{~N}_{2} \mathrm{O}, \mathrm{C}: 80.87, \mathrm{H}$ : $6.79, \mathrm{~N}: 7.86$; found: $\mathrm{C}: 80.86, \mathrm{H}: 6.92, \mathrm{~N}: 7.57$.

Compound 7b: (9-Hexylcarbazol-3-yl)boronic acid pinacol ester (5, $144 \mathrm{mg}, 0.4 \mathrm{mmol}), 2$-bromopyridine-5-carbaldehyde (6b, $47 \mathrm{mg}, 0.3 \mathrm{mmol})$, potassium carbonate $(1 \mathrm{M}, 3 \mathrm{~mL})$ and dichlorobis(triphenylphosphine)palladium(II) (13 mg, $0.02 \mathrm{mmol})$ were dissolved in tetrahydrofuran $(10 \mathrm{~mL})$. The reaction mixture was refluxed for $6 \mathrm{~h}$ under an argon atmosphere. After removing the solvent, the crude product was dissolved in dichloromethane and washed with water $(3 \times 20 \mathrm{~mL})$. The combined extracts were dried over sodium sulfate and then filtered. Upon concentration under reduced pressure, the crude product was obtained as a dark green-yellow liquid. The crude product was first purified by flash column chromatography (dichloromethane/hexane, 1:1 v/v) followed by preparative thinlayer chromatography (hexane/chloroform/MeOH, 10:5:2 $\mathrm{v} / \mathrm{v} / \mathrm{v})$. The pure product $\mathbf{7 b}(67 \mathrm{mg}, 75 \%)$ was obtained as a yellow solid. $R_{\mathrm{f}}$ (dichloromethane/hexane, $\left.5: 1 \mathrm{v} / \mathrm{v}\right)$ : 0.3 ; melting point: $89-91{ }^{\circ} \mathrm{C} ;{ }^{1} \mathrm{H} \mathrm{NMR}\left(600 \mathrm{MHz}, \mathrm{CDCI}_{3}\right) \delta(\mathrm{ppm}): 10.12(\mathrm{~s}$, $1 \mathrm{H}), 9.13(\mathrm{~d}, J=2.2 \mathrm{~Hz}, 1 \mathrm{H}), 8.88(\mathrm{~d}, J=1.8 \mathrm{~Hz}, 1 \mathrm{H})$, $8.26-8.17(\mathrm{~m}, 3 \mathrm{H}), 8.01(\mathrm{~d}, J=8.3 \mathrm{~Hz}, 1 \mathrm{H}), 7.53-7.48(\mathrm{~m}, 2 \mathrm{H})$, $7.44(\mathrm{~d}, J=8.1 \mathrm{~Hz}, 1 \mathrm{H}), 7.29(\mathrm{t}, J=7.4 \mathrm{~Hz}, 1 \mathrm{H}), 4.34(\mathrm{t}, J=$ $7.3 \mathrm{~Hz}, 3 \mathrm{H}), 1.90$ (p, $J=7.4 \mathrm{~Hz}, 2 \mathrm{H}), 1.44-1.25$ (m, 6H), 0.87 $(\mathrm{t}, J=7.1 \mathrm{~Hz}, 3 \mathrm{H}) ;{ }^{13} \mathrm{C}$ NMR $\left(600 \mathrm{MHz}, \mathrm{CDCI}_{3}\right) \delta(\mathrm{ppm})$ 190.5, 163.1, 152.7, 142.0, 141.1, 136.2, 129.1, 128.8, 126.2, $125.3,123.5,123.1,120.7,120.1,119.9,119.5,109.1,109.1$, 43.3, 31.5, 28.9, 26.9, 22.5, 14.0; FTIR $\left(\mathrm{cm}^{-1}\right):$ 2950, 2924 , 
2866, 2852, 2822, 2786, 2724, 1696, anal. calcd for: $\mathrm{C}_{24} \mathrm{H}_{24} \mathrm{~N}_{2} \mathrm{O}, \mathrm{C}: 80.87, \mathrm{H}: 6.79, \mathrm{~N}: 7.86$; found $\mathrm{C}: 80.88, \mathrm{H}$ : 6.91, N: 7.12; MS (EI+, m/z): $356\left(\mathrm{M}^{+}, 73 \%\right), 285$ $\left(\left[\mathrm{M}-\mathrm{C}_{5} \mathrm{H}_{11}\right]^{+}, 100 \%\right)$, HRMS $\left(\mathrm{FAB}^{+}, \mathrm{m} / \mathrm{z}\right)$ : calculated for $\mathrm{C}_{24} \mathrm{H}_{24} \mathrm{~N}_{2} \mathrm{O}[\mathrm{M}]^{+} 356.1889$, found for $[\mathrm{M}]^{+} 356.1893$ (error: $+1.2 \mathrm{ppm})$.

\section{Supporting Information}

The Supporting Information features the followings: 1) ${ }^{1} \mathrm{H}$ NMR and ${ }^{13} \mathrm{C}$ NMR spectra; 2) FTIR spectra; 3) mass and HRMS spectra; 4) calculations of relative fluorescence quantum yields.

\section{Supporting Information File 1}

NMR, FTIR, MS and HRMS spectra of compounds and relative quantum yield calculations.

[https://www.beilstein-journals.org/bjoc/content/ supplementary/1860-5397-16-93-S1.pdf]

\section{Funding}

This work was supported by the Scientific Research Programme Unit (BAP) of Uludag University [KUAP (F)-2018/14]. Nuray Altinolcek thanks the Scientific and Technological Research Council of Turkey (TÜBİTAK) for a Ph.D. scholarship for domestic priority areas (2211-C). Dr. Ahmet Battal thanks the Scientific and Technological Research Council of Turkey (TÜBİTAK) for 2219-International Postdoctoral Research Fellowship Programme for Turkish Citizens. Dr William Peveler acknowledges the University of Glasgow for an LKAS Scholarship, and the EPSRC ERC Capital Award Scheme (EP/ S017984/1) for the Duetta instrument.

\section{ORCID ${ }^{\circledR}$ iDs}

Nuray Altinolcek - https://orcid.org/0000-0002-9553-1474 Ahmet Battal - https://orcid.org/0000-0003-0208-1564 Mustafa Tavasli - https://orcid.org/0000-0002-9466-1111 William J. Peveler - https://orcid.org/0000-0002-9829-2683 Holly A. Yu - https://orcid.org/0000-0002-9559-3376

\section{Preprint}

A non-peer-reviewed version of this article has been previously published as a preprint doi:10.3762/bxiv.2020.25.v1

\section{References}

1. Ledwon, P.; Zassowski, P.; Jarosz, T.; Lapkowski, M.; Wagner, P.; Cherpak, V.; Stakhira, P. J. Mater. Chem. C 2016, 4, 2219-2227. doi:10.1039/c5tc04183j
2. Qian, X.; Zhu, Y.-Z.; Chang, W.-Y.; Song, J.; Pan, B.; Lu, L.; Gao, H.-H.; Zheng, J.-Y. ACS Appl. Mater. Interfaces 2015, 7, 9015-9022. doi:10.1021/am508400a

3. Pan, B.; Wang, B.; Wang, Y.; Xu, P.; Wang, L.; Chen, J.; Ma, D. J. Mater. Chem. C 2014, 2, 2466-2469. doi:10.1039/c3tc32388a

4. Tsai, M.-H.; Lin, H.-W.; Su, H.-C.; Ke, T.-H.; Wu, C.-C.; Fang, F.-C.; Liao, Y.-L.; Wong, K.-T.; Wu, C.-I. Adv. Mater. (Weinheim, Ger.) 2006, 18, 1216-1220. doi:10.1002/adma.200502283

5. Bin, J.-K.; Cho, N.-S.; Hong, J.-I. Adv. Mater. (Weinheim, Ger.) 2012, 24, 2911-2915. doi:10.1002/adma.201200972

6. Park, S.-R.; Kim, S.-M.; Kang, J.-H.; Lee, J.-H.; Suh, M. C. Dyes Pigm. 2017, 141, 217-224. doi:10.1016/j.dyepig.2017.02.014

7. van Dijken, A.; Bastiaansen, J. J. A. M.; Kiggen, N. M. M.; Langeveld, B. M. W.; Rothe, C.; Monkman, A.; Bach, I.; Stössel, P.; Brunner, K. J. Am. Chem. Soc. 2004, 126, 7718-7727. doi:10.1021/ja049771j

8. Ho, C.-L.; Wang, Q.; Lam, C.-S.; Wong, W.-Y.; Ma, D.; Wang, L.; Gao, Z.-Q.; Chen, C.-H.; Cheah, K.-W.; Lin, Z. Chem. - Asian J. 2009, 4, 89-103. doi:10.1002/asia.200800226

9. Wang, Z.; Lu, P.; Xue, S.; Gu, C.; Lv, Y.; Zhu, Q.; Wang, H.; Ma, Y. Dyes Pigm. 2011, 91, 356-363. doi:10.1016/j.dyepig.2011.03.034

10. Ho, C.-L.; Wong, W.-Y.; Gao, Z.-Q.; Chen, C.-H.; Cheah, K.-W.; Yao, B.; Xie, Z.-Y.; Wang, Q.; Ma, D.-G.; Wang, L.-X.; Yu, X.-M.; Kwok, H.-S.; Lin, Z.-Y. Adv. Funct. Mater. 2008, 18, 319-331. doi:10.1002/adfm.200700665

11. Ho, C.-L.; Chi, L.-C.; Hung, W.-Y.; Chen, W.-J.; Lin, Y.-C.; Wu, H.; Mondal, E.; Zhou, G.-J.; Wong, K.-T.; Wong, W.-Y. J. Mater. Chem. 2012, 22, 215-224. doi:10.1039/c1jm13794h

12. Chau, N.-Y.; Ho, P.-Y.; Ho, C.-L.; Ma, D.; Wong, W.-Y. J. Organomet. Chem. 2017, 829, 92-100. doi:10.1016/j.jorganchem.2016.11.018

13. Tavasli, M.; Moore, T. N.; Zheng, Y.; Bryce, M. R.; Fox, M. A.; Griffiths, G. C.; Jankus, V.; Al-Attar, H. A.; Monkman, A. P. J. Mater. Chem. 2012, 22, 6419-6428. doi:10.1039/c2jm15049b

14. Samae, R.; Surawatanawong, P.; Eiamprasert, U.; Pramjit, S.; Saengdee, L.; Tangboriboonrat, P.; Kiatisevi, S. Eur. J. Org. Chem. 2016, 3536-3549. doi:10.1002/ejoc.201600353

15. Chang, Y. J.; Hsu, J.-L.; Li, Y.-H.; Biring, S.; Yeh, T.-H.; Guo, J.-Y.; Liu, S.-W. Org. Electron. 2017, 47, 162-173. doi:10.1016/j.orgel.2017.05.007

16. Zou, Q.; Tao, F.; Wu, H.; Yu, W. W.; Li, T.; Cui, Y. Dyes Pigm. 2019, 164, 165-173. doi:10.1016/j.dyepig.2019.01.023

17. Park, G. J.; You, G. R.; Choi, Y. W.; Kim, C. Sens. Actuators, B 2016, 229, 257-271. doi:10.1016/j.snb.2016.01.133

18. Kala, K.; Manoj, N. RSC Adv. 2016, 6, 22615-22619. doi:10.1039/c5ra27530j

19. Jiao, X.; Xiao, Z.; Hui, P.; Liu, C.; Wang, Q.; Quu, X.; He, S.; Zeng, X.; Zhao, L. Dyes Pigm. 2019, 160, 633-640. doi:10.1016/j.dyepig.2018.08.060

20. Tummachote, J.; Punyain, W.; Thanomsak, S.; Sirikulkajorn, A.; Tomapatanaget, B. Spectrochim. Acta, Part A 2019, 214, 384-392. doi:10.1016/j.saa.2019.02.081

21. Kaur, M.; Yoon, B.; Kumar, R.; Cho, M. J.; Kim, H. J.; Kim, J. S.; Choi, D. H. Bull. Korean Chem. Soc. 2014, 35, 3437-3442. doi:10.5012/bkcs.2014.35.12.3437

22. Niu, L.-Y.; Chen, Y.-Z.; Zheng, H.-R.; Wu, L.-Z.; Tung, C.-H.; Yang, Q.-Z. Chem. Soc. Rev. 2015, 44, 6143-6160. doi:10.1039/c5cs00152h 
23. Guo, F.; Tian, M.; Miao, F.; Zhang, W.; Song, G.; Liu, Y.; Yu, X.; Sun, J. Z.; Wong, W.-Y. Org. Biomol. Chem. 2013, 11, 7721-7728. doi:10.1039/c3ob41414k

24. Xu, N.; Zhang, Q.; Zhang, G. Dalton Trans. 2019, 48, 2683-2691. doi:10.1039/c8dt04558e

25. Liu, H.; Bo, R.; Liu, H.; Li, N.; Xu, Q.; Li, H.; Lu, J.; Wang, L. J. Mater. Chem. C 2014, 2, 5709-5716. doi:10.1039/c4tc00311j

26. Wong, W.-Y.; Ho, C.-L.; Gao, Z.-Q.; Mi, B.-X.; Chen, C.-H.; Cheah, K.-W.; Lin, Z. Angew. Chem., Int. Ed. 2006, 45, 7800-7803. doi:10.1002/anie.200602906

27. Christopher Leslee, D. B.; Karuppannan, S.; Vengaian, K. M.; Gandhi, S.; Subramanian, S. Luminescence 2017, 32, 1354-1360. doi:10.1002/bio.3332

28. Zhang, X.; Chi, Z.; Yang, Z.; Chen, M.; Xu, B.; Zhou, L.; Wang, C.; Zhang, Y.; Liu, S.; Xu, J. Opt. Mater. 2009, 32, 94-98. doi:10.1016/j.optmat.2009.06.009

29. Kim, M.; Lee, J. Y. Adv. Funct. Mater. 2014, 24, 4164-4169. doi:10.1002/adfm.201304072

30. Zhang, J.; Chen, W.; Kalytchuk, S.; Li, K. F.; Chen, R.; Adachi, C.; Chen, Z.; Rogach, A. L.; Zhu, G.; Yu, P. K. N.; Zhang, W.; Cheah, K. W.; Zhang, X.; Lee, C.-S. ACS Appl. Mater. Interfaces 2016, 8, 11355-11365. doi:10.1021/acsami.6b03259

31. Yang, C. L.; Zhang, X. W.; You, H.; Zhu, L. Y.; Chen, L. Q.; Zhu, L. N.; Tao, Y. T.; Ma, D. G.; Shuai, Z. G.; Qin, J. G. Adv. Funct. Mater. 2007, 17, 651-661. doi:10.1002/adfm.200600663

32. Wu, J.; Lai, G.; Li, Z.; Lu, Y.; Leng, T.; Shen, Y.; Wang, C. Dyes Pigm. 2016, 124, 268-276. doi:10.1016/j.dyepig.2015.09.021

33. Grisorio, R.; Piliego, C.; Fini, P.; Cosma, P.; Mastrorilli, P.; Gigli, G.; Suranna, G. P.; Nobile, C. F. J. Phys. Chem. C 2008, 112, 7005-7014. doi:10.1021/jp7102403

34. Saikia, G.; Iyer, P. K. J. Org. Chem. 2010, 75, 2714-2717. doi:10.1021/jo100028d

35. Wang, H.-Y.; Shi, J.-J.; Chen, G.; Xu, X.-P.; Ji, S.-J. Synth. Met. 2012, 162, 241-246. doi:10.1016/j.synthmet.2011.11.013

36. Liu, G.; Li, Y.-H.; Tan, W.-Y.; He, Z.-C.; Wang, X.-T.; Zhang, C.; Mo, Y.-Q.; Zhu, X.-H.; Peng, J.; Cao, Y. Chem. - Asian J. 2012, 7, 2126-2132. doi:10.1002/asia.201200299

37. Strahan, J.; Popere, B. C.; Khomein, P.; Pointer, C. A.; Martin, S. M.; Oldacre, A. N.; Thayumanavan, S.; Young, E. R. Dalton Trans. 2019, 48, 8488-8501. doi:10.1039/c9dt00094a

38. Zhang, K.; Chen, Z.; Yang, C.; Zhang, X.; Tao, Y.; Duan, L.; Chen, L.; Zhu, L.; Qin, J.; Cao, Y. J. Mater. Chem. 2007, 17, 3451-3460. doi:10.1039/b705342h

39. Cardona, C. M.; Li, W.; Kaifer, A. E.; Stockdale, D.; Bazan, G. C. Adv. Mater. (Weinheim, Ger.) 2011, 23, 2367-2371. doi:10.1002/adma.201004554

40. Yun, S.-J.; Seo, H.-J.; Song, M.; Jin, S.-H.; Kim, Y. I. Bull. Korean Chem. Soc. 2012, 33, 3645-3650. doi:10.5012/bkcs.2012.33.11.3645

41. Kang, S. K.; Jeon, J.; Jin, S.-H.; Kim, Y.-I. Bull. Korean Chem. Soc. 2017, 38, 646-650. doi:10.1002/bkcs.11144

42. Bureš, F. RSC Adv. 2014, 4, 58826-58851. doi:10.1039/c4ra11264d

43. Malavolta, L.; Poletti, E. F.; Silva, E. H.; Schreier, S.; Nakaie, C. R. Int. J. Mol. Sci. 2008, 9, 1321-1332. doi:10.3390/ijms9071321

44. Bozkurt, E.; Gül, H. I.; Tuğrak, M. Turk. J. Chem. 2017, 41, 282-293. doi:10.3906/kim-1604-61

45. Casey, K. G.; Quitevis, E. L. J. Phys. Chem. 1988, 92, 6590-6594. doi:10.1021/j100334a023

\section{License and Terms}

This is an Open Access article under the terms of the Creative Commons Attribution License (http://creativecommons.org/licenses/by/4.0). Please note that the reuse, redistribution and reproduction in particular requires that the authors and source are credited.

The license is subject to the Beilstein Journal of Organic Chemistry terms and conditions: (https://www.beilstein-journals.org/bjoc)

The definitive version of this article is the electronic one which can be found at: doi:10.3762/bjoc. 16.93 